\title{
Effects of different factors on adventitious bud induction from stem explants of Ludisia discolor
}

\author{
Ying Liu ${ }^{1}$, Xiaohao $\mathrm{Li}^{1}$, Jingye Chen ${ }^{1}$, Yingbin $\mathrm{Xue}^{2^{*}}$ and Yinling $\mathrm{Zhu}^{2 *}$ \\ ${ }^{1}$ College of Coastal Agricultural Sciences, Guangdong Ocean University, Zhanjiang 524088, P.R. China \\ ${ }^{2}$ College of Chemistry and Environment, Guangdong Ocean University, Zhanjiang 524088, P.R. China
}

\begin{abstract}
In this study, the stem explants of Ludisia discolor were used as experimental materials to investigate the effects of 6-BA, NAA, $\mathrm{Cu}^{2+}$ and $\mathrm{Ag}^{+}$on the induction of adventitious bud regeneration, and to analyze the most suitable culture conditions for stem explants regeneration. The results showed that when the medium was supplemented with $1.0 \mathrm{mg} / \mathrm{L} 6-\mathrm{BA}, 0.75 \mathrm{mg} / \mathrm{L} \mathrm{NAA}, 0.25 \mathrm{mg} / \mathrm{L} \mathrm{CuSO}$, or $6.4 \mathrm{mg} / \mathrm{L} \mathrm{AgCl}$, the best regeneration effects would be gained, respectively. And the adventitious bud regeneration rate reached the maximum, which were $61.67 \%, 83.67 \%, 80.95 \%$ and $87.63 \%$, respectively. The results of this study provided a theoretical basis for tissue culture and rapid propagation of $L$. discolor.
\end{abstract}

\section{Introduction}

Ludisia discolor ((Ker-Gawl.) A. Rich.) is a medicinal plant belonging to Orchidaceae and the genus of Ludisia. It is often called "Goldenline Orchidaceae" [1]. Ludisia discolor is mainly distributed in China, Vietnam, Malaysia, Thailand and other places [2]. It can be found in northern and central Guangdong of China, Hong Kong, Hainan, Guangxi, and southeast of Yunnan, and mainly growing in the damp places under the slopes or gully evergreen broad-leaved forests at an altitude of $900 \sim$ $1300 \mathrm{~m}[3]$.

L. discolor has a sweet and cool taste, which has the functions of nourishing Yin, moistening lung, strengthening spleen and calming nerves [4]. It is mainly used to treat tuberculosis, hemoptysis, loss of appetite, neurasthenia and other diseases [4]. Due to its high medicinal value, $L$. discolor has been widely exploited and utilized. With the excessive exploitation and adoption of human beings, the wild resources are becoming less and less and on the verge of extinction. Moreover, $L$. discolor has been listed as a second-class national protected plant in China [5]. Therefore, if artificial cultivation methods such as plant tissue culture and rapid propagation are adopted, the shortage of wild $L$. discolor germplasm resources can not only be alleviated, but also providing material basis for the cultivation of high-quality $L$. discolor varieties and the high valuable products, and providing scientific basis for the protection of wild germplasm resources of L. discolor [6].

This study aims to explore the effects of different factors on the regeneration of adventitious bud from stem explants of L. discolor, hoping to find the most suitable conditions for adventitious bud induction, and to provide reference for the rapid propagation of $L$. discolor.

\section{Materials and Methods}

\subsection{Experimental materials}

The aseptic seedlings of $L$. discolor used in this study was provided by Professor Yang Yuesheng, College of Life Sciences, South China Agricultural University. The stems of $0.5-1.0 \mathrm{~cm}$ of aseptic seedlings of $L$. discolor were used as explants.

\subsection{Experimental reagents}

The main reagents used in this experiment were 6-BA (6-benzylamino purine), NAA (naphthalene acetic acid), $\mathrm{CuSO}_{4}, \mathrm{AgCl}$, sucrose, MS basic medium, inositol and agar powder, which were purchased from Beijing Solarbio Science \& Technology Co., Ltd.

\subsection{Experimental apparatus}

The main instruments required for the experiment were: magnetic stirrers (MS-H280-Pro), analytical balance (DTT-FA200), adjustable pipet nozzle (Eppendorf), $\mathrm{pH}$ meter (PHS-3E), autoclaves (LX-C75L and LDZX50KBS), refrigerators (BCD-201E/A), and ultra-clean table (SW-CJ-2D). As well as beaker $(500 \mathrm{~mL}, 1000$ $\mathrm{mL})$, measuring cylinder $(100 \mathrm{~mL}, 1000 \mathrm{~mL})$, alcohol lamp $(250 \mathrm{~mL})$, burette, glass rod, scalpel, tweezers, etc.

\subsection{Preparation of mediums and condition of culture}

The same conditions of culture were suitable for all experiments. The $\mathrm{pH}$ was controlled from 5.8 to 6.0 by 1

\footnotetext{
*Corresponding author: Yingbin Xue, yingbinxue@yeah.net; Yinling Zhu, 995143667@qq.com
} 
$\mathrm{mol} / \mathrm{L} \mathrm{NaOH}$ before the mediums were autoclaved for 15 $\mathrm{min}$ at $0.1 \mathrm{MPa}$. The mediums were inoculated at $25 \pm$ $2{ }^{\circ} \mathrm{C}$ with $12 \mathrm{~h}$ photoperiod of cool white fluorescent tubes with a $60-80 \mu \mathrm{mol} \cdot \mathrm{m}^{-2} \cdot \mathrm{s}^{-1}$ intensity.

\subsection{Inducing adventitious bud regeneration from stem explants of $L$. discolor}

To investigate the effects of different concentrations of 6-BA $(0,1.0,3.0$ and $5.0 \mathrm{mg} / \mathrm{L})$, NAA $(0,0.25,0.5$ and $0.75 \mathrm{mg} / \mathrm{L}), \mathrm{CuSO}_{4}(0,0.25,0.5$ and $1.0 \mathrm{mg} / \mathrm{L})$, and $\mathrm{AgCl}(0,3.2,6.4$ and $12.8 \mathrm{mg} / \mathrm{L})$ on adventitious bud regeneration induced by stem explants of $L$. discolor, the explants were inoculated on the base medium for 60 days of culture.

\subsection{Analysis of data}

Regeneration rate $=$ (number of explants with buds $/$ total number of explants) $\times 100 \%$

Average number of buds per explant $=$ total number of buds / total number of explants

The collected data can be summarized by using SPSS 22.0 and Duncan multiple comparisons $(P \leq 0.05)$. The data obtained after comparison was expressed as mean \pm standard error. And significant difference was represented by different letters.

\section{Results}

\subsection{Results of 6-BA concentration on shoot regeneration from stem explants}

It could be seen from Table 1 that the experimental group supplemented with $1.0 \mathrm{mg} / \mathrm{L}$ 6-BA had the highest regeneration rate and the most buds per explant, with the regeneration rate of $61.67 \%$ and average number of buds per explant of 1.45 . With increasing the concentration of 6-BA, the effect of adventitious bud regeneration would decrease gradually.

Table 1. Effects of the concentrations of 6-BA on the production of adventitious bud from stem explants.

\begin{tabular}{|c|c|c|}
\hline $\begin{array}{c}\text { Concentrations of } \\
\text { 6-BA }(\mathrm{mg} / \mathrm{L})\end{array}$ & $\begin{array}{c}\text { Rate of } \\
\text { regeneration } \\
(\%)\end{array}$ & $\begin{array}{c}\text { Average number } \\
\text { of buds per } \\
\text { explant }\end{array}$ \\
\hline 0 & $40.00 \pm 2.43 \mathrm{~d}$ & $0.75 \pm 0.14 \mathrm{~b}$ \\
\hline 1 & $61.67 \pm 0.16 \mathrm{a}$ & $1.45 \pm 0.21 \mathrm{a}$ \\
\hline 3 & $58.33 \pm 0.32 \mathrm{~b}$ & $1.38 \pm 0.27 \mathrm{a}$ \\
\hline 5 & $47.62 \pm 1.38 \mathrm{c}$ & $0.73 \pm 0.18 \mathrm{~b}$ \\
\hline
\end{tabular}

Note: Different letters represent significant differences. In this experiment, $\mathrm{MS}+1.5 \mathrm{mg} / \mathrm{L} \mathrm{NAA}$ was used as the basal medium.

\subsection{Effects of NAA on inducing adventitious bud regeneration from stem explants}

The Table 2 showed that the effects of adventitious bud regeneration of stem explants was affected by NAA (Figure 1A-D). As the concentrations of NAA increased, the effect of adventitious bud regeneration would also be better. When the concentration of NAA was at 0.75 $\mathrm{mg} / \mathrm{L}$, the best regeneration effect could be obtained. And then the average value of buds in the experimental group was 2.13, and the regeneration rate was $83.67 \%$ (Figure 1D).

Table 2. Effects of NAA on inducing adventitious bud regeneration from stem explants

\begin{tabular}{|c|c|c|}
\hline $\begin{array}{c}\text { Concentrations of } \\
\text { NAA (mg/L) }\end{array}$ & $\begin{array}{c}\text { Rate of } \\
\text { regeneration } \\
(\%)\end{array}$ & $\begin{array}{c}\text { Average number } \\
\text { of buds per } \\
\text { explant }\end{array}$ \\
\hline 0 & $73.33 \pm 1.37 \mathrm{c}$ & $1.33 \pm 0.17 \mathrm{c}$ \\
\hline 0.25 & $77.78 \pm 1.26 \mathrm{~b}$ & $1.83 \pm 0.09 \mathrm{ab}$ \\
\hline 0.5 & $79.17 \pm 0.27 \mathrm{~b}$ & $1.93 \pm 0.16 \mathrm{ab}$ \\
\hline 0.75 & $83.67 \pm 0.30 \mathrm{a}$ & $2.13 \pm 0.13 \mathrm{a}$ \\
\hline
\end{tabular}

Note: Different letters represent significant differences. In this experiment, $\mathrm{MS}+0.5 \mathrm{mg} / \mathrm{L}$ 6-BA was used as the basal medium.
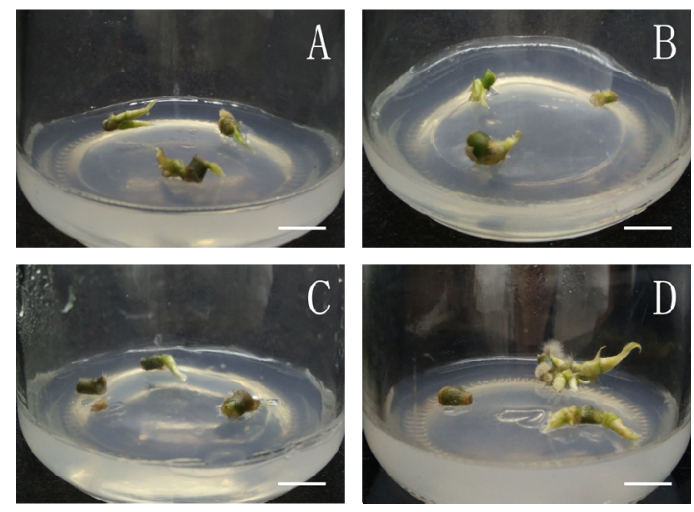

Figure. 1 Effect of concentrations of NAA on the induction of adventitious bud

(A) $0 \mathrm{mg} / \mathrm{L}$, (B) $0.25 \mathrm{mg} / \mathrm{L}$, (C) $0.5 \mathrm{mg} / \mathrm{L}$ and (D) $0.75 \mathrm{mg} / \mathrm{L}$ NAA. $($ Bars $=1 \mathrm{~cm})$

\subsection{Influences of copper sulfate $\left(\mathrm{CuSO}_{4}\right)$ on shoot regeneration from stem explants}

It could be clearly seen from Table 3 that $\mathrm{CuSO}_{4}$ had a significant effect on the regeneration of stem explants. When the concentration of $\mathrm{CuSO}_{4}$ was $0.25 \mathrm{mg} / \mathrm{L}$, the effect of adventitious bud regeneration was the best, and the regeneration rate and the average number of buds per explant could reach the maximum values, which were $80.95 \%$ and 1.73, respectively. However, the regeneration of adventitious bud from stem explants would be inhibited with increasing the concentrations of $\mathrm{CuSO}_{4}$. Therefore, the optimal concentration of $\mathrm{CuSO}_{4}$ is at $0.25 \mathrm{mg} / \mathrm{L}$. 
Table 3. Influences of $\mathrm{CuSO}_{4}$ on shoot regeneration from stem explants

\begin{tabular}{|c|c|c|}
\hline $\begin{array}{c}\text { Concentrations of } \\
\mathrm{CuSO}(\mathrm{mg} / \mathrm{L})\end{array}$ & $\begin{array}{c}\text { Rate of } \\
\text { regeneration } \\
(\%)\end{array}$ & $\begin{array}{c}\text { Average number } \\
\text { of buds per } \\
\text { explant }\end{array}$ \\
\hline 0 & $58.33 \pm 1.32 \mathrm{~d}$ & $1.00 \pm 0.22 \mathrm{c}$ \\
\hline 0.25 & $80.95 \pm 0.18 \mathrm{a}$ & $1.73 \pm 0.16 \mathrm{a}$ \\
\hline 0.5 & $77.78 \pm 0.27 \mathrm{~b}$ & $1.47 \pm 0.15 \mathrm{ab}$ \\
\hline 1 & $73.33 \pm 2.37 \mathrm{c}$ & $1.21 \pm 0.13 \mathrm{bc}$ \\
\hline
\end{tabular}

Note: Different letters represent significant differences. In this experiment, $\mathrm{MS}+5.0 \mathrm{mg} / \mathrm{L}$ 6-BA was used as the basal medium.

\subsection{Effects of silver chloride $(\mathrm{AgCl})$ on adventitious bud induction from stem explants}

It was shown from Table 4 that $\mathrm{AgCl}$ had an obvious effect on the induction of adventitious bud regeneration from stem explants. As the concentration of $\mathrm{AgCl}$ increased gradually, the effect of adventitious bud regeneration was better. When the concentration of $\mathrm{AgCl}$ was $6.4 \mathrm{mg} / \mathrm{L}$, the average number of buds and regeneration rate of the experimental groups were the highest, the average number of buds was 1.75 , and the regeneration rate was $87.63 \%$. However, with increasing the concentration of $\mathrm{AgCl}$, the regeneration efficiency of adventitious buds would decrease. Therefore, the optimal concentration of $\mathrm{AgCl}$ is $6.4 \mathrm{mg} / \mathrm{L}$.

Table 4. Effects of $\mathrm{AgCl}$ on adventitious bud induction from stem explants.

\begin{tabular}{|c|c|c|}
\hline $\begin{array}{c}\text { Concentrations of } \\
\mathrm{AgCl}(\mathrm{mg} / \mathrm{L})\end{array}$ & $\begin{array}{c}\text { Rate of } \\
\text { regeneration } \\
(\%)\end{array}$ & $\begin{array}{c}\text { Average number } \\
\text { of buds per } \\
\text { explant }\end{array}$ \\
\hline 0 & $66.67 \pm 0.30 \mathrm{~d}$ & $1.05 \pm 0.06 \mathrm{c}$ \\
\hline 3.2 & $81.00 \pm 2.26 \mathrm{~b}$ & $1.43 \pm 0.19 \mathrm{ab}$ \\
\hline 6.4 & $87.63 \pm 0.17 \mathrm{a}$ & $1.75 \pm 0.23 \mathrm{a}$ \\
\hline 12.8 & $75.00 \pm 1.30 \mathrm{c}$ & $1.29 \pm 0.11 \mathrm{~b}$ \\
\hline
\end{tabular}

Note: Different letters represent significant differences. In this experiment, MS $+0.2 \mathrm{mg} / \mathrm{L} 6-\mathrm{BA}+0.2 \mathrm{mg} / \mathrm{L}$ NAA was used as the basal medium.

\section{Discussion}

As a member of the cytokinin family, 6-BA plays a significant role in the differentiation and proliferation of adventitious bud in plant $[7,8]$. Our study showed that 6 BA could promote cell division and differentiation at a low concentration, thus accelerating adventitious bud regeneration of stem explants of $L$. discolor. However, a high concentration of 6-BA might cause cell division and over-differentiation, resulting in inhibitory effect.
Similar results were found in the tissue culture experiment of Echinacea purpurea [9].

NAA plays a dual role in promoting cell classification and elongation in plants, and its effect depends on age of cell, concentration of NAA and type of organ [10]. In this study, the appropriate concentration of NAA can promote the regeneration of adventitious buds from stem explants of $L$. discolor.

$\mathrm{Cu}^{2+}$ is an essential trace element for most plants and indispensable for plant growth [11]. However, excessive copper has a toxic effect on plants, leading to the disturbance of various physiological metabolism such as water metabolism, photosynthesis and respiration in plants [11]. In this study, the presence of copper affected the induction effect of regeneration buds of $L$. discolor. Low concentration of $\mathrm{Cu}^{2+}$ could promote the regeneration of adventitious buds, but if the concentration was too high, it would inhibit the regeneration of adventitious bud. It has been shown that appropriate concentration of $\mathrm{Cu}^{2+}$ can promote the differentiation of plant cells [12].

$\mathrm{Ag}^{+}$is a special kind of heavy metal, which has been used as a fungicide for a long time because of its ability to break primitive bacterial proteins without causing damage to tissues and cells [13]. Other studies have shown that $\mathrm{Ag}^{+}$can promote callus induction from apical bud explants in Paeonia suffruticosa and the browning rate is very low [14]. Our study showed that the appropriate concentration of $\mathrm{Ag}^{+}$could promote the regeneration of adventitious bud from stem explants of $L$. discolor, but too high concentration of $\mathrm{Ag}^{+}$could inhibit the regeneration of adventitious bud. This might be explained by the fact that the existence of $\mathrm{Ag}^{+}$could inhibit the growth of bacteria in the culture medium, reducing the pollution rate of medium. Then, low concentration of $\mathrm{Ag}^{+}$could improve the regeneration of adventitious bud, and high concentration of $\mathrm{Ag}^{+}$might be due to higher levels, resulting in destroying bacteria protein and damaging the plant cells, inhibition of adventitious bud induction and growth.

\section{Conclusion}

In the present study, the stem explants of Ludisia discolor were used as experimental materials to investigate the effects of 6-BA, NAA, $\mathrm{Cu}^{2+}$ and $\mathrm{Ag}^{+}$on the induction of adventitious bud regeneration, and to analyze the most suitable culture conditions for stem explants regeneration. Those results suggested that when the basic media was supplemented with $1.0 \mathrm{mg} / \mathrm{L} \mathrm{6-BA,}$ $0.75 \mathrm{mg} / \mathrm{L} \mathrm{NAA}, 0.25 \mathrm{mg} / \mathrm{L} \mathrm{CuSO}_{4}$, or $6.4 \mathrm{mg} / \mathrm{L} \mathrm{AgCl}$, the best regeneration effects would be obtained, respectively. Meanwhile, the regeneration rate of adventitious bud reached the maximum, which were $61.67 \%, 83.67 \%, 80.95 \%$ and $87.63 \%$, respectively.

\section{Acknowledgement}

This research was funded by the Natural Science Foundation of Guangdong Province (2018A030310057 and 2020A1515011570), Nanhai Youth Scholar Project 
of Guangdong Ocean University (002029001012), Program for Scientific Research Start-up Funds of Guangdong Ocean University (R17023 and R19031), Foundation of Education Department of Guangdong Province (2019KTSCX059), the Project of Science and Technology of Zhanjiang City (2020B01019), the National Natural Science Foundation of China (32002131).

\section{References}

1. Q. Zhu, J.W. Ding, X.W. Yang, et al. Tissue culture and rapid propagation of Ludisia discolor. Plant Physiol. 50, 805-809 (2014)

2. Editorial Board of Flora of China. Chinese Academy of Sciences. Flora of China, Vol.17, Orchidaceae. Beijing: Science Press. 157 (1990)

3. Editorial Board of Flora of Hainan. Flora of Hainan (Vol. 4). Science Press. 199 (1977).

4. Z.X. Lin. Research progress of the ornamental southern medicine resource Ludisia discolor. Fujian Hot Prod. Tech. 37, 4-5 (2012)

5. P. Ranjetta, Z. Rahmad, M. Vikneswaran, et al. Autofluorescence study and selected cyanidin quantification in the Jewel orchids Anoectochilus sp. and Ludisia discolor. PLoS One. 13, 1-18 (2018)

6. C.L. Zhang, Y. F. Zhong, X. Q. Song, et al. Comparative analysis of the nutritional value of Ludisia discolor under different cultivation methods. Mol. Plant Breeding. 18, 323-331 (2020)

7. L.H. Cui. The effect of plant growth regulators on adventitious roots of adventitious buds in tissue culture. J. Liaoning Tech. Coll. 2, 97-99 (2000)

8. L.S. Wu, X.P. Wang. Research progress in tissue culture of aquatic ornamental plants. Heilongjiang Agr. Sci. 5, 25-28 (2008)

9. Y.P. Yang, Y.W. Li, Q.W. Li, et al. Establishment of efficient regeneration system of Echinacea purpurea, J. South China Norm. Univ. 47, 94-97 (2015)

10. Y.C. Tian. Effects of NAA treatment to seed of cucumber for germination and seedling growth. J. Chifeng Univ. 30, 18-20 (2014)

11. W.Q.N. Sai, R.L. Ran, M.D. Zhang, et al. Physiological toxicity of astragalus seedlings and mitigation effect of attapulgite clay under copper stress. China Environ. Sci. 39, 5273-5284 (2019)

12. L. Purnhauser, G. Gyulai. Effect of copper on shoot and root regeneration in wheat, triticale, rape and tobacco tissue cultures. Plant Cell Tiss. Organ. Cult. 35, 131-139 (1993)

13. H.Y. Li. Infrared spectroscopy study on the sterilization mechanism of silver nanoparticles and silver ions. Hebei Univ. (2016)

14. C.C. Mao. Effects of different factors on early induction of peony somatic embryogenesis, Henan Agr. Univ. (2015) 